Review

\title{
Intertwining of Activin A and TGFß Signaling: Dual Roles in Cancer Progression and Cancer Cell Invasion
}

\author{
Holli A. Loomans ${ }^{1}$ and Claudia D. Andl ${ }^{1,2,3,4,5, *}$
}

1 Department of Cancer Biology, Vanderbilt University Medical Center, Nashville, TN 37232, USA;

E-Mail: holli.a.loomans@vanderbilt.edu

2 Department of Surgery, Vanderbilt University Medical Center, Nashville, TN 37232, USA

3 Vanderbilt Ingram Cancer Center, Vanderbilt University Medical Center, Nashville, TN 37232, USA

4 Vanderbilt Digestive Disease Center, Vanderbilt University Medical Center, Nashville, TN 37232, USA

5 Vanderbilt Epithelial Biology Center, Vanderbilt University Medical Center, Nashville,

TN 37232, USA

* Author to whom correspondence should be addressed; E-Mail: claudia.andl@vanderbilt.edu; Tel.: +1-615-322-0376; Fax: +1-615-322-6174.

Academic Editor: Scott A. Weed

Received: 7 October 2014 / Accepted: 23 December 2014 / Published: 30 December 2014

\begin{abstract}
In recent years, a significant amount of research has examined the controversial role of activin A in cancer. Activin A, a member of the transforming growth factor $\beta$ (TGF $\beta$ ) superfamily, is best characterized for its function during embryogenesis in mesoderm cell fate differentiation and reproduction. During embryogenesis, TGF $\beta$ superfamily ligands, TGF $\beta$, bone morphogenic proteins (BMPs) and activins, act as potent morphogens. Similar to TGF $\beta$ s and BMPs, activin A is a protein that is highly systemically expressed during early embryogenesis; however, post-natal expression is overall reduced and remains under strict spatiotemporal regulation. Of importance, normal post-natal expression of activin A has been implicated in the migration and invasive properties of various immune cell types, as well as endometrial cells. Aberrant activin A signaling during development results in significant morphological defects and premature mortality. Interestingly, activin A has been found to have both oncogenic and tumor suppressor roles in cancer. Investigations into the role of activin $\mathrm{A}$ in prostate and breast cancer has demonstrated tumor suppressive effects, while in lung and head and neck squamous cell carcinoma, it has been consistently shown that activin A expression is correlated with increased proliferation, invasion and poor patient prognosis. Activin A signaling is highly context-dependent, which is demonstrated in studies
\end{abstract}


of epithelial cell tumors and the microenvironment. This review discusses normal activin A signaling in comparison to TGF $\beta$ and highlights how its dysregulation contributes to cancer progression and cell invasion.

Keywords: TGF $\beta$; activin A; cell adhesion; cell migration; EMT; cancer

\section{Introduction}

As a growing body of research has unraveled the functional consequences of transforming growth factor $\beta$ (TGF $\beta$ ) superfamily signaling, it has also revealed the complexity of these signaling networks and their pleiotropic effects. This family of ligands consists of TGF $\beta$, bone morphogenic proteins (BMPs), activins and anti-Müllerian hormone (AMH) proteins. Of these proteins, TGF $\beta$ and BMPs have been well characterized for their roles in development, angiogenesis and epithelial-to-mesenchymal transition (EMT) during cancer, particularly regarding cell migration and invasion [1-7]. Conversely, activin A signaling is less well understood. Activins are homo- or hetero-dimers of activin $\beta$ subunits. Currently, there are three known bioactive activin dimers: activins $A\left(\beta_{A} \beta_{A}\right), B\left(\beta_{B} \beta_{B}\right)$ and $A B$ $\left(\beta_{\mathrm{A}} \beta_{\mathrm{B}}\right)$ [8-15]. Activin $\mathrm{A}$ is best understood for its function in embryogenesis and reproduction; however, its role during cancer progression is still not well documented. This review focuses on the current understanding of normal activin A signaling, the functional similarities and differences between activin A and TGF $\beta$ and how this signaling pathway becomes dysregulated during cancer progression, influencing cell migration and invasion. Understanding the regulatory mechanism of activin A in cell migration and invasion will allow for better insight into its role in cancer initiation and progression.

\section{Signaling Regulation}

\subsection{Activin A and TGF $\beta$ Signaling}

Though activin A and TGF $\beta$ show structural similarity, activin A is secreted as an active protein, whereas TGF $\beta$ is secreted as an inactive precursor and requires activation [16]. Multiple proteins have been identified that can activate latent TGF $\beta$, including proteolytic processing by plasmin and cathepsin D, as well as nonproteolytic processing by heat and detergents [17].

Not only do TGF $\beta$ superfamily ligands share structural similarity (they share six to nine cysteine residues that form disulfide bonds), the receptor complexes often overlap ligand specificity and downstream signal transduction [18]. TGF $\beta$ receptor complexes are heteromeric complexes that consist of a type I and type II receptor homodimer [19]. Type II and I receptors are distinguished by their sequence. Type II receptors are constitutively active transmembrane serine/threonine kinases [20]. These receptors initially bind a TGF $\beta$ superfamily ligand to recruit a type I receptor and begin the signal transduction cascade. The number of known type II receptors is limited: transforming growth factor $\beta$ receptor II (TGF $\beta$ RII) preferentially binds TGF $\beta$; bone morphogenic protein receptor II (BMPRII) is known to bind multiple ligands, including inhibin A; activin receptor type II and IIB (ActRII/IIB) bind several ligands, of particular interest activin $\mathrm{A}$, inhibin $\mathrm{A} / \mathrm{B}$, and nodal; and the Müllerian inhibitory substance type II receptor (MISRII), which is only known to bind AMH (summarized in [21]). Type I 
receptors, commonly termed activin receptor-like kinases (ALKs), contain highly-conserved kinase domains and a glycine-serine rich juxtamembrane domain, a necessary component for their phosphorylation and activation [22,23]. To date, seven ALKs (ALK1-7) are known and have been characterized. These receptors have been succinctly summarized elsewhere [21]. TGF $\beta$ has been shown to preferentially signal through ALK5 (T $\beta$ RI), while activin A signals primarily via ALK4 [24]. Interestingly, ALK5 and ALK4 show almost identical kinase domains; however, they dimerize with different type II receptors [25].

Focusing specifically on activin A signaling, the signaling pathway begins with an active activin A ligand secreted from the cell. Activin A binds to ActRII/IIB, which recruits a type I receptor, preferentially ALK4, to form a signal transducing heterodimer [9,26-28]. In a similar mechanism to TGF $\beta$ signaling, Smad2/3 is recruited and phosphorylated by ALK4. Active Smad2/3 is released into the cytoplasm and complexes with the co-Smad, Smad4. This complex translocates to the nucleus, where it binds to Smad binding elements, with the consensus sequence CAGA, to drive transcription of downstream effectors (Figure 1A). In addition to this canonical activin A pathway, non-canonical signaling, such as Akt/PI3K, MAPK/ERK and Wnt/ $\beta$-catenin, have been associated with activin A function independently of Smad activation (Figure 1B) [29,30]. Despite their overlapping Smad-dependent or non-canonical pathways, activin A and TGF $\beta$ operate through common, as well as distinct, downstream transcriptional targets, resulting in different functional consequences [31-35].

Due to the overlapping signal transduction pathway of activin A and TGF $\beta$, it is difficult to untangle specific downstream transcriptional targets for the respective pathways. The best-defined differential downstream targets of activin A and TGF $\beta$ signaling are in the context of human embryonic stem cells (hESCs). In hESCs, activin A drives downstream transcription of Nanog, whereas TGF $\beta$ signaling in this context induces the transcription of SRY-box 2 (Sox2) and octamer binding protein-4 (Oct4) to induce self-renewal and differentiation, which is negatively regulated through the activation of BMP signaling [36-39]. In adult tissues, discerning between activin A and TGF $\beta$ signaling is more difficult. Both activin A and TGF $\beta$, via the Smad2/3/4 complex, have been shown to regulate various cell cycle and extracellular matrix proteins, such as p15, plasminogen activator-1 (PAI-1) and collagen I [40]. With the advent of new methodologies, future research should focus on unweaving differential activin $\mathrm{A}$ and TGF $\beta$ signaling in post-natal tissues.

\subsection{Mechanism of Activin A Regulation}

Activin A expression is tightly regulated. Regulators of the activin A signaling cascade can be found in the extracellular matrix, at the cell membrane and intracellularly (Figure 2A,B) [41-43]. As there are numerous mechanisms of activin A regulation, we have focused specifically on the most studied, best understood mechanisms of activin A regulation, follistatin and inhibin A, endogenous inhibitors found at the cell membrane and in circulation [44-47]. Follistatin is expressed in three forms, follistatin-288, follistatin-303 and follistatin-315 [48,49], with different modes of action (Figure 2A). Two follistatin proteins surround and inhibit activin A by blocking access to both the activin receptor type I and II binding sites [45,50,51]. Follistatin-288, which is mainly found at the cell membrane, sequesters activin A, resulting in endocytosis and lysosomal degradation [1-7,51-54]. Follistatin-288 function itself can be regulated through cleavage at the cell surface by heparin and function in circulation $[8-15,51,54,55]$. Follistatin-303 is produced in relatively low abundance compared to the other follistatin isoforms and 
has moderate affinity for cell surface proteoglycans, but can bind activin $\mathrm{A}$ in circulation, as well as at the cell membrane $[1,9,26-28,37,49]$. The effects of activin A signaling can also be counteracted by a structurally-related ligand, inhibin $A$. Inhibin $A$ is a heterodimer composed of inhibin $\alpha$ and $\beta_{A}$ subunits $[29,30,56,57]$. Inhibin A, bound to the transmembrane receptor, betaglycan (TBRIII), dimerizes with ActRII/IIB, preventing activin A binding [31-35,58,59]. TGF $\beta$ signaling demonstrates similar levels of regulation, indicating the importance of maintaining the signaling balance of this superfamily [2,4,6,41-43,60,61]. Additional mechanisms of activin A regulation on the extra- and intra-cellular levels are shown in Figure 2.

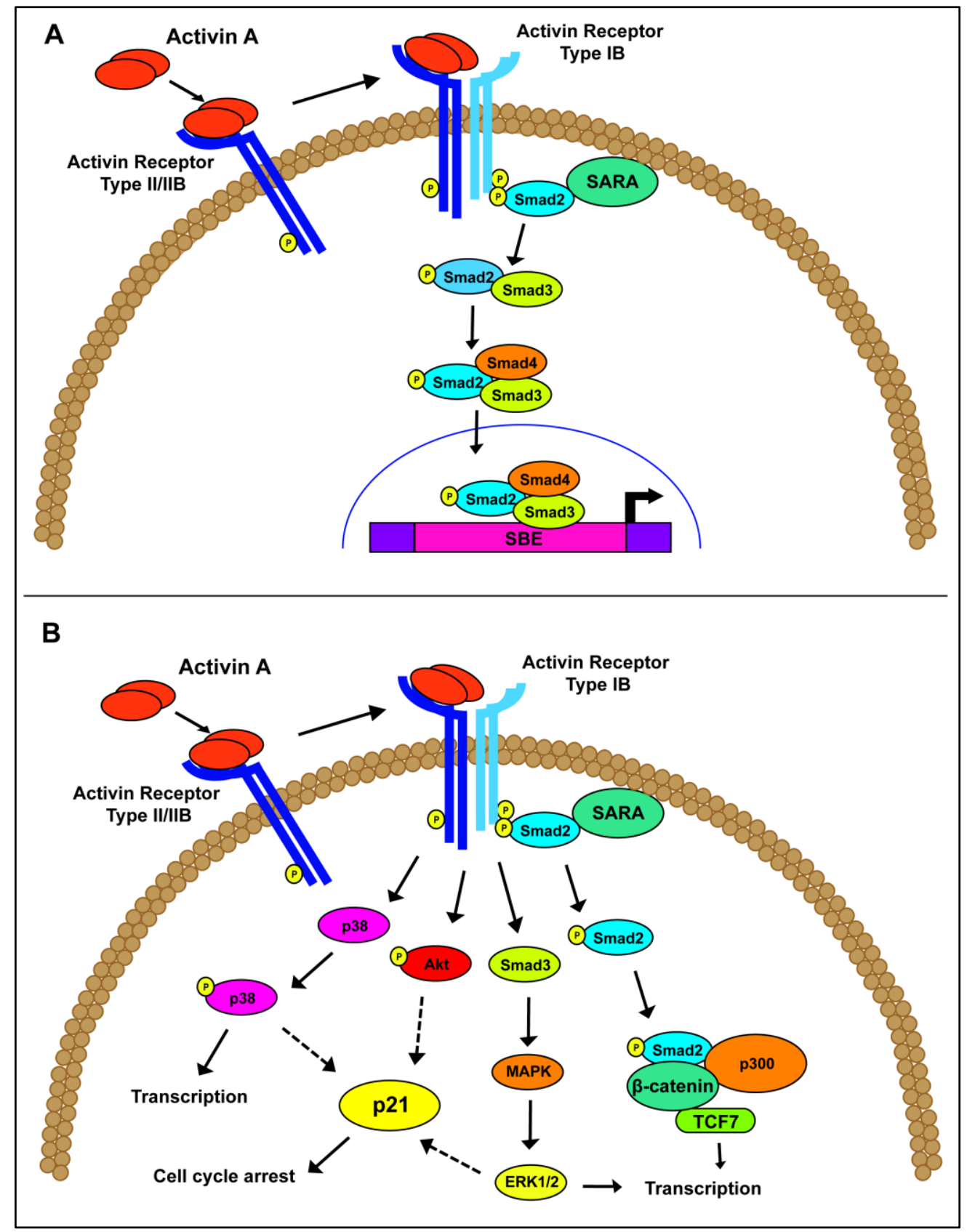

Figure 1. Schematic of activin A signaling. (A) Canonical activin A signaling occurs through the phosphorylation and activation of the Smad proteins, leading to downstream gene transcription. (B) Non-canonical activin A signaling has been postulated through a variety of pathways, including P13K/Akt, MAPK/ERK and $\beta$-catenin/p300. 


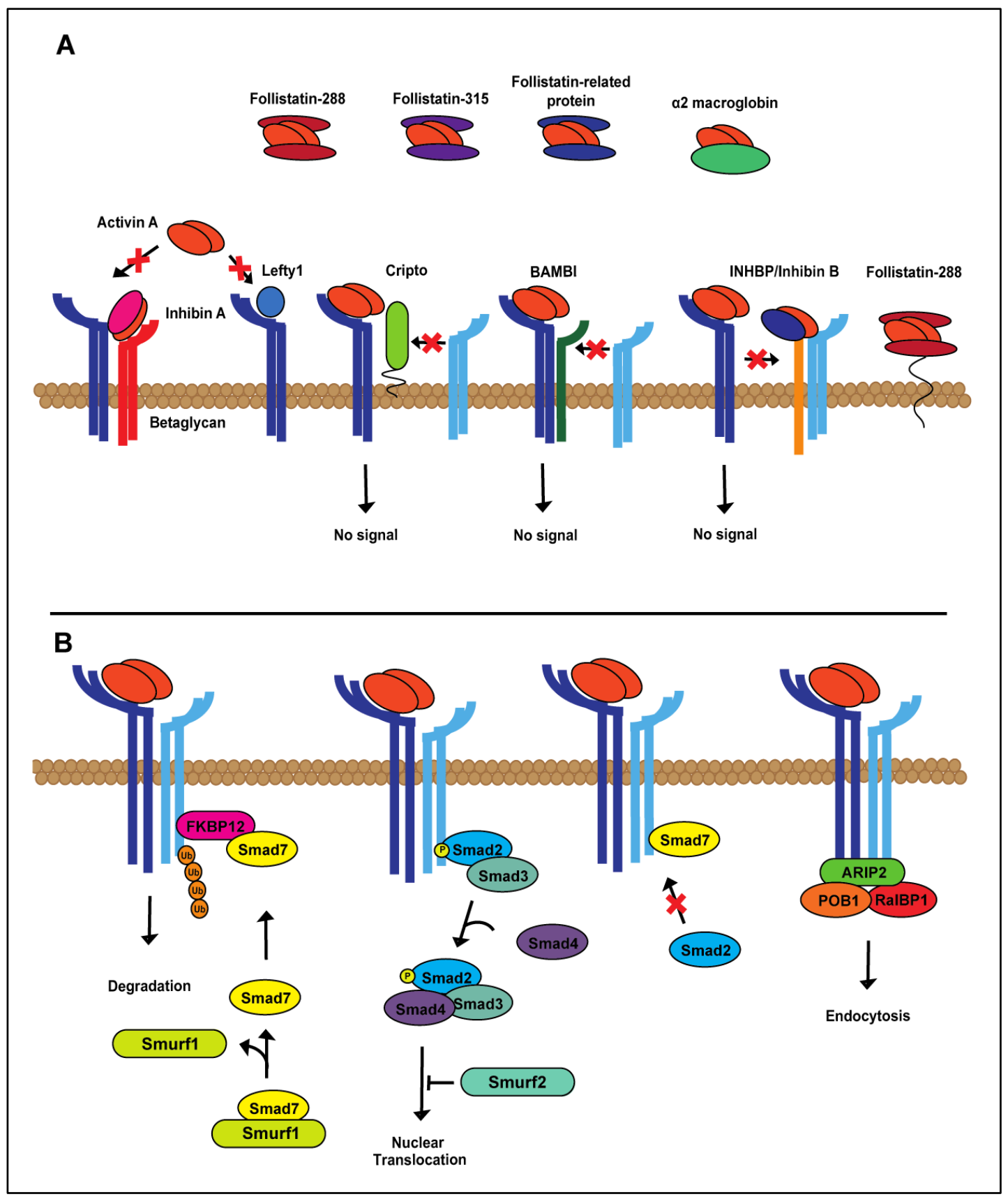

Figure 2. Extra- and intra-cellular regulation of activin A signaling. (A) Activin A is tightly regulated at the extracellular level by both extracellular matrix (follistatin-288, follistatin-315, follistatin-related protein, $\alpha 2$-macroglobin, left-right determination factor 1 (Lefty1), inhibin A) and membrane-bound proteins (betaglycan, Cripto, BAMBI, INHBP/inhibin B, follistatin-288). (B) In the cytoplasm, canonical activin A signaling is controlled during each step of the Smad cascade.

\section{Hijacked Developmental Processes and Their Contributions in Tumorigenesis}

\subsection{Early Development and Stem Cell Biology}

Embryonic development requires particular populations of cells to undergo EMT, migration and complete implantation and gastrulation [44-47,56,62]. Activin A plays a significant part in this process. 
Initially described as XTC-MIF, activin A was found to be a potent morphogen and inducer of the mesodermal patterning $[11,13,15,26,48,49,63,64]$. With increasing concentrations, activin A can induce mesodermal cell differentiation, inducing epidermal cell fate at the lowest concentrations, as well as Spemann organizer patterning at the highest concentrations [9,26-28,45,50,51,61,65,66]. Spatial patterning occurs via a diffusible activin A concentration gradient in the extracellular matrix (ECM) [29,67]. Interestingly, TGF $\beta$ plays a minor role in these developmental processes. Similar to activin A, TGF $\beta$ diffuses along a similar gradient; however, it does not induce the same spectrum of cell fates as activin A does and requires a much higher concentration of TGF $\beta$ ligand $[31,51,54,68]$.

In human development, activin A is necessary to maintain pluripotency and the subsequent differentiation of human pluripotent stem cells (hPSC) [50,69]. Prolonged treatment of hPSC with activin A induces definitive endoderm differentiation [52,70]. During early hPSC differentiation, activin/nodal signaling is critical to induce epithelial-mesodermal switching, indicated by the loss of the epithelial marker, CD326 (epithelial cell adhesion molecule, EPCAM), and upregulation of mesodermal marker CD56 (neural cell adhesion molecule 1, NCAM1) [55,59,71]. Activin A, in concert with Nodal, signals through Smad2/3 to induce Nanog expression, which is necessary to maintain the expression of genes involved in pluripotency [1,3,7,37]. Maintaining pluripotency in cells is necessary, not only to achieve proper development, but also to initiate and sustain tumorigenesis. Activin A has been shown to be necessary for the maintenance of self-renewal in human embryonic stem cells through the induction of Oct4, Nanog, nodal and wingless-type MMTV integration site family member 3 (Wnt3) [36] and, more importantly, the induction of basic fibroblast growth factor 2 (FGF-2) and suppression of BMP7 [72]. Suppression of the downstream target inhibitor of DNA binding 2 (Id2) by activin A and TGF $\beta$ is central in the induction of EMT, which is antagonized by BMPs [73]. Of interest, EMT is associated with the acquisition of malignant traits and stem cell markers, therefore linking TGF $\beta$ signaling to the regulation of cancer stem cells [74].

\subsection{EMT vs. Collective Migration}

Different members of the TGF $\beta$ superfamily (TGF $\beta 1$, TGF $\beta 2$, TGF $\beta 3$, activin A or BMP7) have been analyzed for their potential to induce EMT in epithelial cells of different origins. While TGF $\beta 1$, TGF $\beta 2$ and TGF $\beta 3$ induce characteristic features of EMT in the mammary and lung cells along with the downregulation and delocalization of E-cadherin, activin A does not induce EMT in mammary cells or keratinocytes, but causes the scattering and spindle-like morphology of lung cells [75]. As EMT is widely recognized to lead to increased cell invasion, loss of E-cadherin is a hallmark of EMT [76]. TGF $\beta$ participates in the EMT process through the regulation of transcription factors, such as Snail family zinc finger 1 (Snail), zinc finger E-box binding homeobox 1(ZEB) and twist family BHLH transcription factor 1 (twist), which suppress the E-cadherin expression. E-cadherin repressors function as EMT inducers on multiple levels, but when cells at the invasive front lose E-cadherin expression, single cell migration occurs [77]. Yet, cell migration in a cohesive group is a hallmark of the tissue remodeling events that underlie embryonic morphogenesis, wound repair and cancer invasion [78]. The mode of sheet migration relies on the cooperative guidance of leader and follower cells throughout the collective group. TGF $\beta$ has been shown to stimulate collective migration primarily through extracellular-regulated kinase 1/2 (ERK1/2) activation [79]. On the other hand, using a three-dimensional organotypic culture 
system, we have described that inhibition of TGF $\beta$ signaling increases collection into the underlying extracellular matrix in a fibroblast- and MMP-dependent manner [80]. Additional research has demonstrated that tumor cell knockout of TGF $\beta$ signaling, through deletion of the type II receptor, drives fibroblast-stimulated collective migration and metastasis [81].

\subsection{Wound Healing and Regeneration}

Embryogenesis and wound healing enlist similar processes, such as the programmed death of unneeded or damaged cells and cell migration. Wound healing is an elaborate, tightly-regulated process: Briefly, following tissue injury, growth factors and cytokines are released at the wound site. Injured vessels begin to clot due to the deposition of ECM proteins, such as fibronectin and collagen, and form granulation tissue. Over the course of the next several days to weeks, immune cells and fibroblasts infiltrate the granulation tissue, ridding it of debris and rebuilding the matrix $[10,12,14,56]$. Throughout the process, all cell types require the ability to move, replace and reform tissue. In zebrafish, activin A is required for tissue regeneration following injury, while inhibition of signaling completely blocks regeneration [58,82-84]. In a mouse model of wound repair, increased Inhba, which encodes the mouse $\beta_{\mathrm{A}}$ subunit, was observed in wound granulation tissue within one day of injury and was sustained for seven days $[2,4,6,9,61,85]$. As follistatin levels increased concurrently with inhibin $\beta_{\mathrm{A}}$ levels, it has been suggested that the availability of the activin A ligand, not receptor occupation, regulates the wound response $[9,26,28,56,85]$. Activin A levels become quickly elevated in wounded tissues, likely due to the early inflammatory response $[11,13,15,26,63,64,86]$. However, as demonstrated in embryogenesis, activin A operates in a concentration-dependent manner. When activin $\mathrm{A}$ is overexpressed in the skin, wounds heal more quickly, however being associated with substantial fibrosis [27,61,66,87-89].

TGF $\beta$ has been highly characterized to promote a reactive stroma $[65,89,90]$. Similarly to activin A, TGF $\beta$ can support all aspects of wound granulation tissue, such as attracting macrophages and fibroblasts to the injury site, initiate wound angiogenesis and stimulate ECM deposition and inflammation [50,67,91]. During wound healing, activin A and TGF $\beta$ function in similar roles.

\section{Contributions to Tumorigenesis}

Harold Dvorak elegantly described cancer as being "the wound that does not heal". Activin A and TGF $\beta$ are excellent examples of this phenomenon, as they both show similar functions in development and wound healing to that observed in cancer initiation and progression. Interestingly, both ligands demonstrate cell type and context-dependent roles within the tumor microenvironment, illustrated below (Figure 3).

\subsection{Epithelial Tumors}

As the role of activin A has been explored in a variety of epithelial tumors, differences in action emerged between cancers. It has been shown that activin A can exert a primarily protective function $[51,52,54,68,92]$. Experiments utilizing patient-derived prostate cancer cells and non-invasive LNCaP have demonstrated that treatment with activin A results in cell cycle arrest [45,93-95]. Interestingly, LNCaP cells showed no response when treated with the exogenous TGF $\beta$ ligand $[96,97]$. 
In contrast, activin A treatment of the more aggressive prostate cancer cell line PC3 resulted in an increase in proliferation $[69,98]$. Recent evidence has implicated endoglin, a TGF $\beta$ type III receptor and co-receptor, in cancer cell invasion in prostate cancer cell lines via activin A signaling, though endoglin has primarily been shown to propagate the signal by forming a complex with TGF $\beta$ and its receptors [99]. Co-expression of endoglin and ActRIIA, when expressed on PC3 or DU-145 cells, has shown suppressed cancer cell invasion, while co-expression of endoglin with ActRIIB, BMP and TGF $\beta$ does not exhibit this effect. This functional effect is likely mediated through non-canonical Smad signaling; however, the mechanism of action needs to be further explored [100]. Additionally, TGF $\beta$ has an oncogenic effect on PC3 cells, as well as the breast cancer cell line, MDA-MB-231. When acting via the non-canonical MAPK/TRAF6 pathway, TGF $\beta$ induces a pro-migratory, invasive phenotype $[70,101]$. An in vitro analysis of 15 breast cancer cell lines detected activin A expression in only four cell lines $[59,71,102]$. Functionally, when treated with activin A, T47D cells showed the induction of cyclin-dependent kinase inhibitors p21 and p27 and the cell cycle control protein p1 $5^{\mathrm{INK} 4 \mathrm{~B}}$, as well as the downregulation of cyclin A, resulting in increased apoptosis and cell cycle arrest. Similarly, MCF7 cells, which have no detectable endogenous activin A, are highly sensitive to the growth inhibitory effects of activin A [1,3,5,7]. In early tumorigenesis, TGF $\beta$ has been shown to have a similar effect. In an overlapping pathway to activin A signaling, TGF $\beta$ induces cell cycle arrest through the induction of the cyclin-dependent kinase inhibitors p15 ${ }^{\text {INK4B }}$, p16 ${ }^{\text {INK4A }}$, p21 and p27 $[8,10,12,14]$. However, in some cancers, tumor cells lose their ability to respond to the growth inhibitory effects of both activin A and TGF $\beta$. This occurs primarily through mutation or downregulation of the receptor; however, this is not always the case $[2,4,6,82-84,103]$.

In contrast to its characteristic growth inhibitory effects, activin A expression has also been associated with inducing an invasive phenotype in certain cancers (Figure 3). In lung adenocarcinoma and oral squamous cell carcinomas, for example, activin A overexpression is correlated with positive lymph node status and poor patient prognosis $[9,11,13,15,85,104,105]$. In head and neck squamous cell carcinoma, increased activin $\mathrm{A}$ has been hypothesized to be an independent prognostic marker of survival $[9,26-28,85,106]$. In vitro treatment of the lung cancer cell lines, H460 and SKLU1, with recombinant activin A showed increased proliferation [26,29,30,63,86,107-109]. Additionally, treatment with recombinant activin A increased invasion in the ovarian cancer cell lines, SKOV-3 and OCC1, without impacting proliferation [110].

MMP-7, a matrix metalloproteinase capable of degrading many components of the ECM and activating additional MMPs responsible for increased cell invasion, is upregulated in the presence of activin A [31-35,87-89,109]. This occurs through c-Jun/Smad activity inducing MMP-7 transcription via the AP-1 promoter region [41-43,89,90,111]. Additionally, in vitro and clinical evidence suggest that activin A may drive cell invasion by upregulating N-cadherin, a marker of mesenchymal cells and invasiveness [44-47,50,91,112]. N-cadherin expression is positively correlated with activin A, regardless of E-cadherin expression [48,49,52,92,113-115].

In a similar mechanism to activin A, TGF $\beta$ has also been shown to promote cancer cell progression. TGF $\beta$ is a potent inducer of EMT through its canonical Smad signaling pathway, as demonstrated in various cancer cell types. TGF $\beta$ prompts the expression of Snail family zinc finger 2 (Slug), Snail and twist, which act to repress E-cadherin expression $[8,45,50,51,58,93,94,103]$. EMT can also be induced through TGF $\beta$ non-canonical signaling pathways. It has been recently demonstrated that TGF $\beta$ can act through TRAF6 to promote receptor cleavage of ALK5/T $\beta$ RI, which allows for the cleaved intracellular 
domain to translocate to the nucleus and, in association with $\mathrm{p} 300$, drive transcription of various invasion-promoting genes [8,51-54,116,117]. Increased expression of TGF $\beta$ has been noted in various cancers, such as lung, breast and gastric cancers, and has been associated with poor patient prognosis [51,54,55,96,118]. Additionally, TGF $\beta$ can stimulate and alter MMP expression from epithelial cells. Several groups have shown that TGF $\beta$ can negatively regulate MMP-1 and MMP-7 through canonical Smad signaling, while stimulating the production of MMP-2 and MMP-9 through non-canonical p38 and NFkB signaling pathways [1,37,49,98,119]. MMP production and activation are necessary for degrading ECM components, allowing for cell migration and further invasion into the stroma.

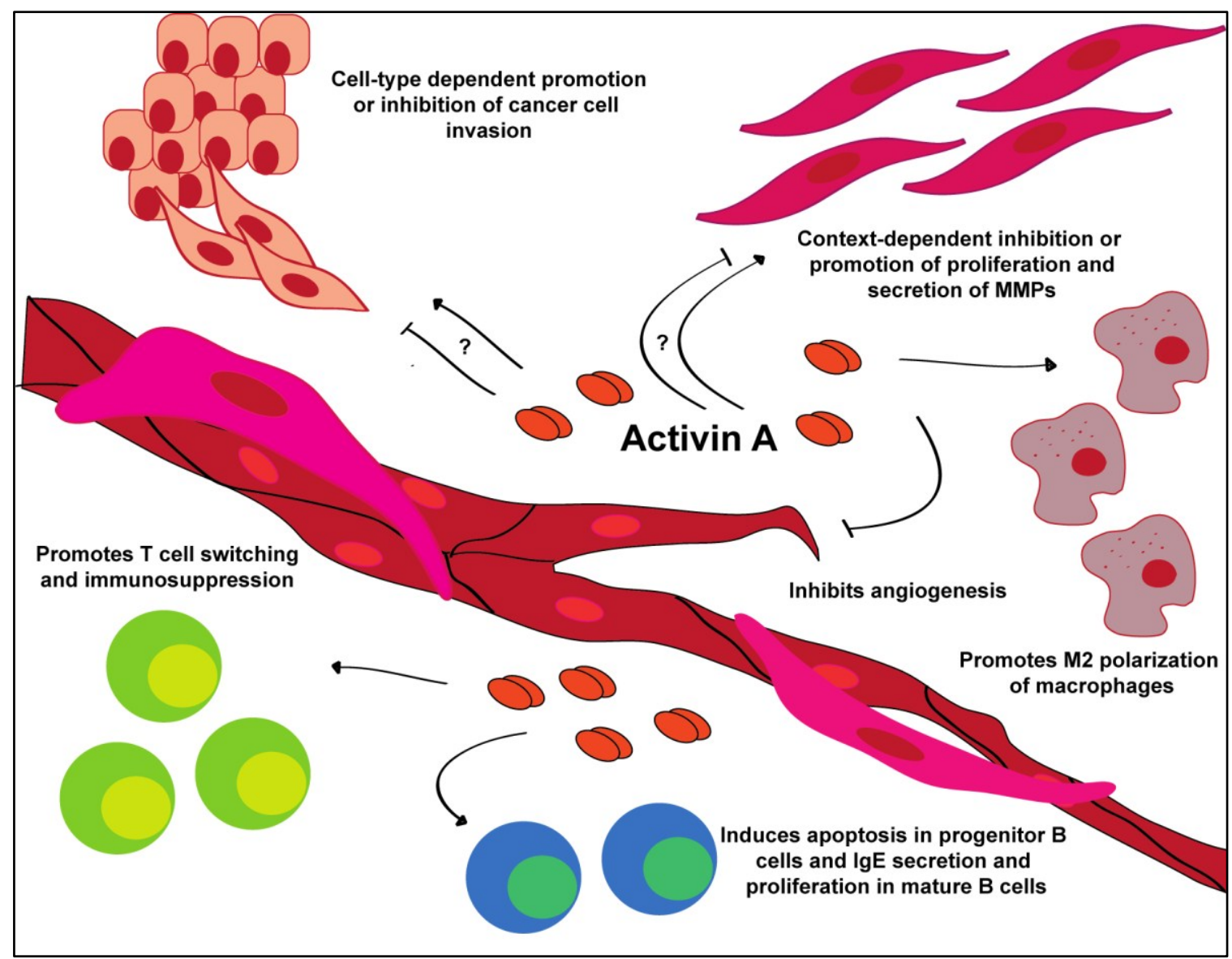

Figure 3. Tumor microenvironmental interactions of activin A. Activin A promotes a variety of behaviors in a cell-type and context-dependent manner.

When overexpressed in the tumor, activin A confers differential effects. Some cancers, such as lung and head and neck squamous cell carcinoma, develop insensitivity to the growth inhibitory effects of activin A, one of the hallmarks of cancer [56,57,101,120]. During cancer progression, cells in the tumor microenvironment, such as T-helper $1\left(\mathrm{~T}_{\mathrm{h}} 1\right)$ cells and fibroblasts, increase their production of activin A in an attempt to inhibit the growth of the tumor; however, the cancer cells adapt and evade these signals. Tumor cells that show resistance to activin A may do so by downregulating ALK4, which is responsible for signal transduction, or by upregulating follistatin or inhibin A production; however, these areas need to be further explored $[58,59,102,121]$. 


\subsection{Immune Cells}

Activin A plays a key role in the maturation and activation of the innate and adaptive immune systems (Figure 3). In the normal immune response, activin $A$ is on the forefront of fighting infection [1,2,4-6,60,61,122]. In the humoral immune response, activin A is secreted by and plays a significant role in the function of adaptive immune cells. In the T-cell population, activin A is secreted specifically by activated CD4+CD25- (CD25: interleukin 2 receptor $\alpha)$ T-helper $2\left(\mathrm{~T}_{\mathrm{h}} 2\right)$ cells $[8,56,62,123,124]$. However, activin A also contributes to the switching of CD4+CD25-Foxp3(Foxp3: forkhead box P3) cells to CD4+CD25+Foxp3+ T-regulatory ( $\mathrm{T}_{\text {reg }}$ ) cells, which correlates with immunosuppression in patients with B-cell acute lymphoblastic leukemia $[11,13,15,26,63,64,103,125]$. $\mathrm{T}_{\text {reg }}$ cells downregulate the actions of $\mathrm{T}_{h} 1, \mathrm{~T}_{\mathrm{h}} 2$ and $\mathrm{T}$-helper $17\left(\mathrm{~T}_{\mathrm{h}} 17\right)$ cells, limiting their ability to recognize and potentially destroy cancer cells. Similarly, TGF $\beta$ induces a similar Foxp $3+\mathrm{T}_{\text {reg }}$ cell phenotype $[9,27,61,66,105,126,127]$. Together, T-cells induced by either activin A or TGF $\beta$ promote a pro-tumor microenvironment.

Activin A induces stage-dependent effects on B-cells [9,26,28,65,106,127]. This has been demonstrated in a variety of studies, where exogenous treatment of B-cells derived from marrow stem cells, cultured cell lines and mature B-cells can induce apoptosis in the former and proliferation and antibody secretion in the latter [29,65,67,107-109]. Additionally, activin A is secreted by activated B-cells, which, in turn, stimulates the production of IgE antibodies $[31,51,54,68,109,128,129]$. TGF $\beta$ performs a similar function as activin A and inhibits the proliferation of progenitor B cells; however, it also has the ability to induce growth arrest in B maturation [41,45,95,111]. Conversely, TGF $\beta$ can drive B-cell differentiation and stimulate the production of $\operatorname{IgE}$ and, in some cells, $\operatorname{IgG}[44,46,47,51,53,54,112,130,131]$.

The effect of activin A in the immune system has been most heavily studied in the macrophages, though activin A has also been shown to affect mast cells, natural killer cells and dendritic cells $[48,97,113-115]$. As discussed above, activin A is secreted by $\mathrm{T}_{\mathrm{h}} 2$-helper cells, which also secrete high levels of interleukin-4 (IL-4) and interleukin-13 (IL-13). IL-4 and IL-13 promote the alternative activation pathway of macrophages, M2, that is commonly associated with wound healing and cancer $[8,50,58,69,103]$. Interestingly, in vitro activin A stimulation promoted the M2 macrophage phenotype, suggesting its functional similarities to IL-4 and IL-13 in tumor promotion [8,52,70,117]. TGF $\beta$ also polarizes macrophages to the alternative M2 phenotype, promoting an immunosuppressive microenvironment [55,59,71,118]. These M2 macrophages secrete cytokines and MMPs that promote a favorable tumor microenvironment [132].

Condeelis and Pollard, in their review of the multifaceted nature of macrophages, succinctly stated that "tumors recruit macrophages and create a microenvironment that causes macrophages to suppress immune functions and, instead, adapt trophic roles found during development and repair" [1,3,7,37,119]. This involves creating a favorable environment for tumor cell invasion and recruitment of fibroblasts and endothelial cells to the microenvironment. For example, secretion of interleukin- 2 and interferon- $\alpha$ from T-cells drive the release of basic fibroblast growth factor, leading to the subsequent induction of endothelial cell and fibroblast migration [36,120]. Activin A and TGF $\beta$ play important roles in this process, reasserting developmental function in the incorrect context, and promote pathogenesis. 


\subsection{Fibroblasts}

Fibroblasts in the tumor microenvironment contribute to the creation of a reactive stroma or the transformed state of the stroma in response to disrupted homeostasis, wounding or cancer initiation [72,121]. In normal physiology, fibroblasts typically express activin A at negligible levels [73,122]. Activin A stimulates proliferation of mouse $3 \mathrm{~T} 3$ fibroblasts, airway smooth muscle cells and lung fibroblasts [74,123,124]. Interestingly, we have shown that overexpression of activin A by normal esophageal fibroblasts in a pre-neoplastic microenvironment inhibits proliferation in both an autocrine and paracrine manner; however, it switches to a tumor promoter in the presence of malignant cells [133]. A similar phenotype has been noted in the context of TGF $\beta$ signaling $[75,126]$.

Tumor-associated myofibroblasts (TAMs) of oral squamous cell carcinoma, which express markers of activation (e.g., $\alpha$-smooth muscle actin ( $\alpha$ SMA), platelet-derived growth factor- $\alpha$ (PDGF $\alpha$ ), fibroblast activating protein (FAP)), secrete increased levels of activin A [76,127,128]. This was associated with increased secretion of collagen I, MMP-1, MMP-2, MMP-9 and MMP-13, as well as increased proliferation and in vivo tumor volume [77,128]. In comparison, the development of a reactive stroma has been correlated with increased secretion of TGF $\beta$ by pre-neoplastic cells $[65,78]$. However, it has been consistently shown that fibroblasts that lose responsiveness to TGF $\beta$ promote collective cell invasion $[79,129,130]$. These results suggest that, in contrast to activin A, TGF $\beta$ signaling in the tumor stroma is necessary to maintain an intact microenvironment and prevent tumor cell invasion, though it has been suggested that TGF $\beta$ may act through the reactive stroma, not the epithelial cell compartment, to promote tumor angiogenesis [2,4,6,80,134]. This is a significant point, where the functional consequences of TGF $\beta$ and activin A diverge.

TAMs secrete proinflammatory cytokines and proteases to drive EMT and proliferation and migration of epithelial and endothelial cells $[11,13,15,81,135,136]$. These results suggest that TAMs can prime the tumor microenvironment for epithelial cancer cell invasion by rearranging the ECM. Additionally, TAMs have been associated with the recruitment of immunosuppressive cells to the tumor front $[10,12,14,27,56,98]$. The localization of myofibroblasts to the tumor has been indicative of poor patient prognosis $[30,58,82-84,137,138]$. The recruitment and activation of fibroblasts at the tumor front results in an aggressive and invasive phenotype, as tumor cells use fibroblasts to alter the ECM.

\subsection{Endothelial Cells}

In contrast to its tumor promoting function in immune cells, activin A has been consistently shown to operate as a potent anti-angiogenic factor (Figure 3). Treatment of endothelial cells demonstrated decreased tube formation and inhibition of proliferation via induction of $\mathrm{p} 21$ and decreased expression of cyclin D1 and Rb [2,4,6,9,32-35,61,85,139,140]. This effect can be overcome by silencing of $\mathrm{p} 21$. Additionally, fibroblast-derived overexpression of activin A downregulates vascular endothelial growth factor (VEGF) expression, one of the key components of tumor angiogenesis [133]. Previous research has shown that most endothelial cells express ActRII/IIB and are therefore able to respond to activin A ligand binding $[9,26,28,42,43,56,85,140]$. Activin A treatment of endothelial cells results in a dose-dependent inhibition of proliferation. Experiments utilizing chick chorioallantoic membrane demonstrated a complete loss of capillary development and fibrosis when treated with activin A 
$[11,13,15,26,45,63,64,86,141]$. In our experiments, conditioned media from normal esophageal fibroblasts that overexpress activin A completely inhibits the tube formation of endothelial cells [133]. In vivo, breast cancer cells expressing activin A develop larger, though less vascularized, tumors compared to cells expressing follistatin, which form smaller, better vascularized tumors $[27,49,61,66,87-89,142]$.

Due to its potent anti-angiogenic nature, cancer cells have developed mechanisms to counteract activin A activity. Activin A expression in neuroblastoma results in elevated cyclin-dependent kinase inhibitors and decreased vascular endothelial growth factor receptor 2 (VEGFR2) [45,51,65,89,90,143]. Therefore, the oncogene N-myc, which is consistently overexpressed in neuroblastoma, stifles this effect by directly inhibiting transcription of the inhibin $\beta_{\mathrm{A}}$ subunit and, subsequently, activin $\mathrm{A}$ homodimer formation [50,51,53,54,67,91,141]. Additionally, activin A may be negatively regulated by interleukin-32 (IL-32), which promotes proliferation and endothelial cell function during tumor promotion. This effect is overcome with the silencing of IL-32, which results in the upregulation of activin A [51,52,54,68,92,144].

TGF $\beta$ has been consistently shown to both induce and inhibit angiogenesis. In contrast to activin A's function, TGF $\beta$ directly stimulates the pro-angiogenic protein, vascular endothelial growth factor A (VEGF-A), via Smad3, while the angiogenesis inhibitor, thrombospondin-1 (THBS1), is induced via phosphorylated Smad2 $[45,49,93-95,145,146]$. These separate signaling pathways suggest differential effects of TGF $\beta$ signaling in cancer development and metastasis. Interestingly, TGF $\beta$-induced angiogenesis can be blocked through treatment with TGF $\beta$ inhibitors, latent activating protein (LAP) and BMP, and activin membrane-bound inhibitor (BAMBI) [57,96,97,134,147]. It may be suggested that TGF $\beta$ promotes endothelial cell migration and tube formation via a VEGF-dependent pathway, as it is well established that VEGF is a potent driver of tip cell migration $[59,69,98,148]$. However, recent research has shown that cells' TGF $\beta$ has the ability to bind to ALK1 and ALK5 on the endothelium, which may then dimerize with endoglin to activate Smad1/5/8, the typical BMP signaling pathway, and inhibit endothelial cell proliferation; however, these results remain controversial $[149,150]$.

\section{Conclusions and Future Directions}

As discussed above, activin A plays pleiotropic roles in basic physiology and pathogenesis. Normal activin A function induces embryonic cell fate, wound healing and inhibits proliferation. During tumorigenesis, activin A acts as a suppressor of cancer angiogenesis, as a promoter of tumor-associated macrophages and T-cells and exerts mixed effects on epithelial tumor cells, further exemplifying the context- and cell type-dependent effects of activin A signaling. Based on the evidence presented, the overall functional consequences of activin A signaling alone are not sufficient to either suppress or drive cancer progression and, therefore, must work in collaboration with other pathways to dictate a particular phenotype. This may include working in cooperation with other TGF $\beta$ ligands, such as BMP4, or synergistically with other pathways, such as MAPK/ERK [37,59,62,71,102,151]. Further investigation into the mechanism of activin A signaling and the intertwining of different pathways to promote cancer progression is needed to unravel the complex signaling processes.

\section{Acknowledgements}

Claudia D. Andl received funding from the National Institute of Health (DK094900, DK091491), and Holli A. Loomans is supported by T32-CA009593 from the National Institute of Health. 


\section{Author Contributions}

The authors contributed equally to this work.

\section{Abbreviations}

TGF $\beta$, transforming growth factor $\beta$; BMP, bone morphogenic protein; ALK1, activin receptor-like 1; ALK4, activin receptor-like kinase 4, ActRIB; ALK5, activin receptor like kinase 5, T $\beta$ RI; ActRII, activin receptor type II; ActRII, activin receptor type II/IIA; MMP, matrix metalloproteinase; $I N H B A$, the inhibin $\beta$ A gene, which encodes the activin $\beta$ A subunit.

\section{Conflicts of Interest}

The authors have no conflict of interest to declare.

\section{References}

1. Brown, S.; Teo, A.; Pauklin, S.; Hannan, N.; Cho, C.H.-H.; Lim, B.; Vardy, L.; Dunn, N.R.; Trotter, M.; Pedersen, R.; et al. Activin/Nodal signaling controls divergent transcriptional networks in human embryonic stem cells and in endoderm progenitors. Stem Cells 2011, 29, 1176-1185.

2. Faure, S.; Lee, M.A.; Keller, T.; ten Dijke, P.; Whitman, M. Endogenous patterns of TGF $\beta$ superfamily signaling during early Xenopus development. Development 2000, 127, 2917-2931.

3. Matzuk, M.M.; Finegold, M.J.; Su, J.-G.J.; Hsueh, A.J.; Bradley, A. $\alpha$-Inhibin is a tumor-suppressor gene with gonadal specificity in mice. Nature 1992, 360, 313-319.

4. Dale, L.; Jones, C.M. BMP signalling in early Xenopus development. Bioessays 1999, 21, 751-760.

5. Jones, K.L.; de Kretser, D.M.; Patella, S.; Phillips, D.J. Activin A and follistatin in systemic inflammation. Mol. Cell. Endocrinol. 2004, 225, 119-125.

6. Kwon, S.J.; Lee, G.T.; Lee, J.-H.; Iwakura, Y.; Kim, W.-J.; Kim, I.Y. Mechanism of pro-tumorigenic effect of BMP-6: Neovascularization involving tumor-associated macrophages and IL-1 $\alpha$. Prostate 2014, 74, 121-133.

7. Burdette, J.E.; Jeruss, J.S.; Kurley, S.J.; Lee, E.J.; Woodruff, T.K. Activin A mediates growth inhibition and cell cycle arrest through Smads in human breast cancer cells. Cancer Res. 2005, 65, 7968-7975.

8. Ogawa, K.; Funaba, M.; Chen, Y.; Tsujimoto, M. Activin A functions as a Th2 cytokine in the promotion of the alternative activation of macrophages. J. Immunol. 2006, 177, 6787-6794.

9. Green, J.B.; New, H.V.; Smith, J.C. Responses of embryonic Xenopus cells to activin and FGF are separated by multiple dose thresholds and correspond to distinct axes of the mesoderm. Cell 1992, 71, 731-739.

10. Katz, L.H.; Li, Y.; Chen, J.-S.; Muñoz, N.M.; Majumdar, A.; Chen, J.; Mishra, L. Targeting TGF- $\beta$ signaling in cancer. Expert Opin. Ther. Targets 2013, 17, 743-760.

11. Muttukrishna, S.; Tannetta, D.; Groome, N.; Sargent, I. Activin and follistatin in female reproduction. Mol. Cell. Endocrinol. 2004, 225, 45-56.

12. Meulmeester, E.; ten Dijke, P. The dynamic roles of TGF- $\beta$ in cancer. J. Pathol. 2010, 223, 206-219. 
13. Vale, W.; Rivier, C.; Hsueh, A.; Campen, C.; Meunier, H.; Bicsak, T.; Vaughan, J.; Corrigan, A.; Bardin, W.; Sawchenko, P. Chemical and biological characterization of the inhibin family of protein hormones. Recent Prog. Horm. Res. 1988, 44, 1-34.

14. Sheen, Y.Y.; Kim, M.-J.; Park, S.-A.; Park, S.-Y.; Nam, J.-S. Targeting the transforming growth factor- $\beta$ signaling in cancer therapy. Biomol. Ther. 2013, 21, 323-331.

15. Barton, D.E.; Yang-Feng, T.L.; Mason, A.J.; Seeburg, P.H.; Francke, U. Mapping of genes for inhibin subunits $\alpha, \beta$-A, and $\beta$-B on human and mouse chromosomes and studies of jsd mice. Genomics 1989, 5, 91-99.

16. Munger, J.S.; Harpel, J.G.; Gleizes, P.-E.; Mazzieri, R.; Nunes, I.; Rifkin, D.B. Latent transforming growth factor- $\beta$ : Structural features and mechanisms of activation. Kidney Int. 2007, 51, 1376-1382.

17. Hyytiäinen, M.; Penttinen, C.; Keski-Oja, J. Latent TGF- $\beta$ binding proteins: Extracellular matrix association and roles in TGF- $\beta$ activation. Crit. Rev. Clin. Lab. Sci. 2004, 41, 233-264.

18. Chang, H.; Brown, C.W.; Matzuk, M.M. Genetic analysis of the mammalian transforming growth factor- $\beta$ superfamily. Endocr. Rev. 2002, 23, 787-823.

19. Attisano, L.; Carcamo, J.; Ventura, F.; Weis, F.M.B.; Massagué, J.; Wrana, J.L. Identification of human activin and TGF $\beta$ type I receptors that form heteromeric kinase complexes with type II receptors. Cell 1993, 75, 1-10.

20. Lin, H.Y.; Wang, X.-F.; Ng-Eaton, E.; Weinberg, R.A.; Lodish, H.F. Expression cloning of the TGF- $\beta$ type II receptor, a functional transmembrane serine/threonine kinase. Cell 1992, 68, 775-785.

21. De Caestecker, M. The transforming growth factor- $\beta$ superfamily of receptors. Cytokine Growth Factor Rev. 2004, 15, 1-11.

22. Franzen, P.; Heldin, C.-H.; Miyazono, K. The GS domain of the transforming growth factor- $\beta$ type I receptor is important in signal transduction. Biochem. Biophys. Res. Commun. 1995, 207, 682-689.

23. Wieser, R.; Wrana, J.L.; Massagué, J. GS domain mutations that constitutively activate T $\beta$ R-1, the downstream signaling component in the TGF- $\beta$ receptor complex. EMBO J. 1995, 14, 2199-2208.

24. Ten Dijke, P.; Yamashita, H.; Ichijo, H.; Franzen, P.; Laiho, M.; Miyazono, K.; Heldin, C.-H. Characterization of type I receptors for transforming growth factor- $\beta$ and activin. Science 1994, 264, 101-104.

25. Carcamo, J.; Weis, F.M.; Ventura, F.; Wieser, R.; Wrana, J.L.; Attisano, L.; Massagué, J. Type I receptors specify growth-inhibitory and transcriptional responses to transforming growth factor $\beta$ and activin. Mol. Cell. Biol. 1994, 14, 3810-3821.

26. Gurdon, J.B.; Harger, P.; Mitchell, A.; Lemaire, P. Activin signalling and response to a morphogen gradient. Nature 1994, 371, 487-492.

27. Hashimoto, O.; Yamato, K.; Koseki, T.; Ohguchi, M.; Ishisaki, A.; Shoji, H.; Nakamura, T.; Hayashi, Y.; Sugino, H.; Nishihara, T. The role of activin type I receptors in activin A-induced growth arrest and apoptosis in mouse B-cell hybridoma cells. Cell. Signal. 1998, 10, 743-749.

28. Symes, K.; Yordán, C.; Mercola, M. Morphological differences in Xenopus embryonic mesodermal cells are specified as an early response to distinct threshold concentrations of activin. Development 1994, 120, 2339-2346.

29. McDowell, N.; Zorn, A.M.; Crease, D.J.; Gurdon, J.B. Activin has direct long-range signalling activity and can form a concentration gradient by diffusion. Curr. Biol. 1997, 7, 671-681. 
30. Heldin, C.-H.; Landström, M.; Moustakas, A. Mechanism of TGF- $\beta$ signaling to growth arrest, apoptosis, and epithelial-mesenchymal transition. Curr. Opin. Cell Biol. 2009, 21, 166-176.

31. McDowell, N.; Gurdon, J.B.; Grainger, D.J. Formation of a functional morphogen gradient by a passive process in tissue from the early Xenopus embryo. Int. J. Dev. Biol. 2001, 45, 199-207.

32. Stankic, M.; Pavlovic, S.; Chin, Y.; Brogi, E.; Padua, D.; Norton, L.; Massagué, J.; Benezra, R. TGF- $\beta$-Id1 signaling opposes Twist 1 and promotes metastatic colonization via a mesenchymal-toepithelial transition. Cell Rep. 2013, 5, 1228-1242.

33. Di, X.; Andrews, D.M.K.; Tucker, C.J.; Yu, L.; Moore, A.B.; Zheng, X.; Castro, L.; Hermon, T.; Xiao, H.; Dixon, D. A high concentration of genistein down-regulates activin A, Smad3 and other TGF- $\beta$ pathway genes in human uterine leiomyoma cells. Exp. Mol. Med. 2012, 44, 281.

34. Frigon, N.L., Jr.; Shao, L.-E.; Young, A.L.; Maderazo, L.; Yu, J. Regulation of globin gene expression in human K562 cells by recombinant Activin A. Blood 1992, 3, 765-772.

35. Gressner, O.A. Intracrine signaling mechanisms of activin A and TGF- $\beta$. Vitam Horm. 2011, 85, 59-77.

36. James, D.; Levine, A.J.; Besser, D.; Hemmati-Brivanlou, A. TGF $\beta /$ activin/nodal signaling is necessary for the maintenance of pluripotency in human embryonic stem cells. Development 2005, $132,1273-1282$.

37. Xu, R.-H.; Sampsell-Barron, T.L.; Gu, F.; Root, S.; Peck, R.M.; Pan, G.; Yu, J.; Antosiewicz-Bourget, J.; Tian, S.; Stewart, R.; et al. NANOG is a direct target of TGF $\beta /$ activin-mediated SMAD signaling in human ESCs. Cell Stem Cell 2008, 3, 196-206.

38. Wrana, J.L. Signaling by the TGF $\beta$ Superfamily. Cold Spring Harb. Perspect. Biol. 2013, 5, a011197-a011197.

39. Beyer, T.A.; Weiss, A.; Khomchuk, Y.; Huang, K.; Ogunjimi, A.A.; Varelas, X.; Wrana, J.L. Switch enhancers interpret TGF- $\beta$ and hippo signaling to control cell fate in human embryonic stem cells. Cell Rep. 2013, 5, 1611-1624.

40. Itoh, F.; Watabe, T.; Miyazono, K. Seminars in cell \& developmental biology. Semin. Cell Dev. Biol. 2014, 32, 98-106.

41. Jones, R.L.; Findlay, J.K.; Farnworth, P.G.; Robertson, D.M.; Wallace, E.; Salamonsen, L.A. Activin A and inhibin A differentially regulate human uterine matrix metalloproteinases: Potential interactions during decidualization and trophoblast invasion. Endocrinology 2006, 147, 724-732.

42. Hedger, M.P.; Winnall, W.R. Regulation of activin and inhibin in the adult testis and the evidence for functional roles in spermatogenesis and immunoregulation. Mol. Cell. Endocrinol. 2012, 359, 30-42.

43. Keutmann, H.T.; Schneyer, A.L.; Sidis, Y. The role of follistatin domains in follistatin biological action. Mol. Endocrinol. 2004, 18, 228-240.

44. Osteen, K.G.; Igarashi, T.M.; Bruner-Tran, K.L. Progesterone action in the human endometrium: Induction of a unique tissue environment which limits matrix metalloproteinase (MMP) expression. Front. Biosci. 2003, 8, d78-d86.

45. De Winter, J.P.; ten Dijke, P.; de Vries, C.J.; van Achterberg, T.A.; Sugino, H.; de Waele, P.; Huylebroeck, D.; Verschueren, K.; van den Eijnden-van Raaij, A.J.M. Follistatins neutralize activin bioactivity by inhibition of activin binding to its type II receptors. Mol. Cell. Endocrinol. 1996, 116, 105-114. 
46. Canigga, I.; Lye, S.J.; Cross, J.C. Activin is a local regulator of human cytotrophoblast cell differentiation. Endocrinology 1997, 138, 3976-3986.

47. Ogawa, K.; Funaba, M.; Mathews, L.S.; Mizutani, T. Activin A stimulates type IV collagenase (matrix metalloproteinase-2) production in mouse peritoneal macrophages. J. Immunol. 2000, 165, 2997-3003.

48. Zhao, J.; Taverne, M.A.M.; van der Weijden, G.C.; Bevers, M.M.; van den Hurk, R. Effect of activin A on in vitro development of rat preantral follicles and localization of activin A and activin receptor II. Biol. Reprod. 2001, 65, 967-977.

49. Schneyer, A.L.; Wang, Q.; Sidis, Y.; Sluss, P.M. Differential distribution of follistatin isoforms: Application of a new FS315-specific immunoassay. J. Clin. Endocrinol. Metab. 2004, 89, 5067-5075.

50. Duggal, G.; Heindryckx, B.; Warrier, S.; O’Leary, T.; van der Jeught, M.; Lierman, S.; Vossaert, L.; Deroo, T.; Deforce, D.; Chuva de Sousa Lopes, S.M.; et al. Influence of activin a supplementation during human embryonic stem cell derivation on germ cell differentiation potential. Stem Cells Dev. 2013, 22, 3141-3155.

51. Thompson, T.B.; Lerch, T.F.; Cook, R.W.; Woodruff, T.K.; Jardetzky, T.S. The structure of the follistatin:activin complex reveals antagonism of both type I and type II receptor binding. Dev. Cell 2005, 9, 535-543.

52. Toivonen, S.; Lundin, K.; Balboa, D.; Ustinov, J.; Tamminen, K.; Palgi, J.; Trokovic, R.; Tuuri, T.; Otonkoski, T. Activin A and Wnt-dependent specification of human definitive endoderm cells. Exp. Cell Res. 2013, 319, 2535-2544.

53. Hashimoto, O.; Nakamura, T.; Shoji, H.; Shimasaki, S.; Hayashi, Y.; Sugino, H. A novel role of follistatin, an activin-binding protein, in the inhibition of activin action in rat pituitary cells. Endocytotic degradation of activin and its acceleration by follistatin associated with cell-surface heparan sulfate. J. Biol. Chem. 1997, 272, 13835-13842.

54. Nakamura, T.; Takio, K.; Eto, Y.; Shibai, H.; Titani, K.; Sugino, H. Activin-binding protein from rat ovary is follistatin. Science $\mathbf{1 9 9 0 , 2 4 7 , 8 3 6 - 8 3 8 .}$

55. Evseenko, D.; Zhu, Y.; Schenke-Layland, K.; Kuo, J.; Latour, B.; Ge, S.; Scholes, J.; Dravid, G.; Li, X.; MacLellan, W.R.; et al. Mapping the first stages of mesoderm commitment during differentiation of human embryonic stem cells. Proc. Natl. Acad. Sci. USA 2010, 107, 13742-13747.

56. Munz, B.; Tretter, Y.P.; Hertel, M.; Engelhardt, F.; Alzheimer, C.; Werner, S. The roles of activins in repair processes of the skin and the brain. Mol. Cell. Endocrinol. 2001, 180, 169-177.

57. Robertson, D.M.; de Vos, F.L.; Foulds, L.M.; McLachlan, R.I.; Burger, H.G.; Morgan, F.J.; Hearn, M.T.W.; de Kretser, D.M. Isolation of a $31 \mathrm{kDa}$ form of inhibin from bovine follicular fluid. Mol. Cell. Endocrinol. 1986, 44, 271-277.

58. Jaźwińska, A.; Badakov, R.; Keating, M.T. Activin- $\beta$ A signaling is required for zebrafish fin regeneration. Curr. Biol. 2007, 17, 1390-1395.

59. Lewis, K.A.; Gray, P.C.; Blount, A.L.; MacConell, L.A.; Wiater, E.; Bilezikjian, L.M.; Vale, W. Betaglycan binds inhibin and can mediate functional antagonism of activin signalling. Nature 2000, 404, 411-414.

60. Miyazono, K. Positive and regative regulation of TGF- $\beta$ signaling. J. Cell Sci. 2000, 113, 1101-1109.

61. Hübner, G.; Hu, Q.; Smola, H.; Werner, S. Strong induction of activin expression after injury suggests an important role of activin in wound repair. Dev. Biol. 1996, 173, 490-498. 
62. Acloque, H.; Adams, M.S.; Fishwick, K.; Bronner-Fraser, M.; Nieto, M.A. Epithelial-mesenchymal transitions: The importance of changing cell state in development and disease. J. Clin. Invest. 2009, 119, 1438-1449.

63. Green, J.B.; Howes, G.; Symes, K.; Cooke, J.; Smith, J.C. The biological effects of XTC-MIF: Quantitative comparison with Xenopus bFGF. Development 1990, 108, 173-183.

64. Yndestad, A.; Ueland, T.; Øie, E.; Florholmen, G.; Halvorsen, B.; Attramadal, H.; Simonsen, S.; Frøland, S.S.; Gullestad, L.; Christensen, G.; et al. Elevated levels of activin A in heart failure: Potential role in myocardial remodeling. Circulation 2004, 109, 1379-1385.

65. Tuxhorn, J.A.; Ayala, G.E.; Smith, M.J.; Smith, V.C.; Dang, T.D.; Rowley, D.R. Reactive stroma in human prostate cancer: Induction of myofibroblast phenotype and extracellular matrix remodeling. Clin. Cancer Res. 2002, 8, 2912-2923.

66. Sulyok, S.; Wankell, M.; Alzheimer, C.; Werner, S. Activin: An important regulator of wound repair, fibrosis, and neuroprotection. Mol. Cell. Endocrinol. 2004, 225, 127-132.

67. Roberts, A.B.; Sporn, M.B. Differential expression of the TGF- $\beta$ isoforms in embryogenesis suggests specific roles in developing and adult tissues. Mol. Reprod. Dev. 1992, 32, 91-98.

68. Reis, F.M.; Cobellis, L.; Tameirão, L.C.; Anania, G.; Luisi, S.; Silva, I.S.B.; Gioffrè, W.; di Blasio, A.M.; Petraglia, F. Serum and tissue expression of activin a in postmenopausal women with breast cancer. J. Clin. Endocrinol. Metab. 2002, 87, 2277-2282.

69. Hofland, J.; van Weerden, W.M.; Steenbergen, J.; Dits, N.F.J.; Jenster, G.; de Jong, F.H. Activin A stimulates AKR1C3 expression and growth in human prostate cancer. Endocrinology 2012, 153, 5726-5734.

70. Thakur, N.; Gudey, S.K.; Marcusson, A.; Fu, J.Y.; Bergh, A.; Heldin, C.-H.; Landström, M. TGF $\beta$-induced invasion of prostate cancer cells is promoted by c-Jun-dependent transcriptional activation of Snail1. Cell Cycle 2014, 13, 2400-2414.

71. Liu, Q.Y.; Niranjan, B.; Gomes, P.; Gomm, J.J.; Davies, D.; Coombes, R.C.; Buluwela, L. Inhibitory effects of activin on the growth and morpholgenesis of primary and transformed mammary epithelial cells. Cancer Res. 1996, 56, 1155-1163.

72. Xiao, L.; Yuan, X.; Sharkis, S.J. Activin A maintains self-renewal and regulates fibroblast growth factor, Wnt, and bone morphogenic protein pathways in human embryonic stem cells. Stem Cells 2006, 24, 1476-1486.

73. Kowanetz, M.; Valcourt, U.; Bergström, R.; Heldin, C.-H.; Moustakas, A. Id2 and Id3 define the potency of cell proliferation and differentiation responses to transforming growth factor $\beta$ and bone morphogenetic protein. Mol. Cell. Biol. 2004, 24, 4241-4254.

74. Polyak, K.; Weinberg, R.A. Transitions between epithelial and mesenchymal states: Acquisition of malignant and stem cell traits. Nat. Rev. Cancer 2009, 9, 265-273.

75. Valcourt, U.; Kowanetz, M.; Niimi, H.; Heldin, C.-H.; Moustakas, A. TGF $\beta$ and the Smad signaling pathway support transcriptomic reprogramming during epithelial-mesenchymal cell transition. Mol. Biol. Cell 2005, 16, 1987-2002.

76. Le Bras, G.F.; Taubenslag, K.J.; Andl, C.D. The regulation of cell-cell adhesion during epithelial-mesenchymal transition, motility and tumor progression. Cell Adh. Migr. 2012, 6, 365-373.

77. Thiery, J.P.; Acloque, H.; Huang, R.Y.J.; Nieto, M.A. Epithelial-mesenchymal transitions in development and disease. Cell 2009, 139, 871-890. 
78. Friedl, P.; Gilmour, D. Collective cell migration in morphogenesis, regeneration and cancer. Nat. Rev. Mol. Cell Biol. 2009, 10, 1-13.

79. Chapnick, D.A.; Liu, X. Leader cell positioning drives wound-directed collective migration in TGF $\beta$-stimulated epithelial sheets. Mol. Biol. Cell 2014, 25, 1586-1593.

80. Le Bras, G.F.; Taylor, C.; Koumangoye, R.B.; Revetta, F.; Loomans, H.A.; Andl, C.D. TGF $\beta$ loss activates ADAMTS-1-mediated EGF-dependent invasion in a model of esophageal cell invasion. Exp. Cell Res. 2014, 330, 29-42.

81. Matise, L.A.; Palmer, T.D.; Ashby, W.J.; Nashabi, A.; Chytil, A.; Aakre, M.; Pickup, M.W.; Gorska, A.E.; Zijlstra, A.; Moses, H.L. Lack of transforming growth factor- $\beta$ signaling promotes collective cancer cell invasion through tumor-stromal crosstalk. Breast Cancer Res. 2012, 14, R98.

82. Fink, S.P.; Mikkola, D.; Willson, J.K.V.; Markowitz, S. TGF- $\beta$-induced nuclear localization of Smad2 and Smad3 in Smad4 null cancer cell lines. Oncogene 2003, 22, 1317-1323.

83. Jeruss, J.S.; Sturgis, C.D.; Rademaker, A.W.; Woodruff, T.K. Down-regulation of activin, activin receptors, and Smads in high-grade breast cancer. Cancer Res. 2003, 63, 3783-3790.

84. Togashi, Y.; Sakamoto, H.; Hayashi, H.; Terashima, M.; de Velasco, M.A.; Fujita, Y.; Kodera, Y.; Sakai, K.; Tomida, S.; Kitano, M.; et al. Homozygous deletion of the activin A receptor, type IB gene is associated with an aggressive cancer phenotype in pancreatic cancer. Mol. Cancer 2014, $13,1-15$.

85. Kelner, N.; Rodrigues, P.C.; Bufalino, A.; Fonseca, F.; dos Santos-Silva, A.R.; Miguel, M.C.C.; Pinto, C.A.L.; Leme, A.F.P.; Graner, E.; Salo, T.; et al. Activin A immunoexpression as predictor of occult lymph node metastasis and overall survival in oral tongue squamous cell carcinoma. Head Neck 2014, doi:10.1002/hed.23627.

86. Seder, C.W.; Hartojo, W.; Lin, L.; Silvers, A.L.; Wang, Z.; Thomas, D.G.; Giordano, T.J.; Chen, G.; Chang, A.C.; Orringer, M.B.; et al. Upregulated INHBA expression may promote cell proliferation and is associated with poor survival in lung adenocarcinoma. Neoplasia 2009, 11, 388-396.

87. Matzuk, M.M.; Kumar, T.R.; Vassalli, A.; Bickenbach, J.R.; Roop, D.R.; Jaenisch, R.; Bradley, A. Functional analysis of activins during mammalian development. Nature 1995, 374, 354-356.

88. Sang, Q.A.; Bodden, M.K.; Windsor, L.J. Activation of human progelatinase A by collagenase and matrilysin: Activation of procollagenase by matrilysin. J. Protein Chem. 1996, 15, 243-253.

89. Yoshinaga, K.; Mimori, K.; Inoue, H.; Kamohara, Y.; Yamashita, K.; Tanaka, F.; Mori, M. Activin A enhances MMP-7 activity via the transcription factor AP-1 in an esophageal squamous cell carcinoma cell line. Int. J. Oncol. 2008, 33, 453-459.

90. Brown, C.W.; Houston-Hawkins, D.E.; Woodruff, T.K.; Matzuk, M.M. Insertion of Inhbb into the Inhba locus rescues the Inhba-null phenotype and reveals new activin functions. Nat. Genet. 2000, $25,453-457$.

91. Suyama, K.; Shapiro, I.; Guttman, M.; Hazan, R.B. A signaling pathway leading to metastasis is controlled by N-cadherin and the FGF receptor. Cancer Cell 2002, 2, 301-314.

92. Yoshinaga, K.; Inoue, H.; Utsunomiya, T.; Sonoda, H.; Masuda, T.; Mimori, K.; anaka, Y.; Mori, M. $\mathrm{N}-\mathrm{Cadherin}$ is regulated by Activin A and associated with tumor aggressiveness in esophageal carcinoma. Clin. Cancer Res. 2004, 10, 5702-5707. 
93. Cufí, S.; Vazquez-Martin, A.; Oliveras-Ferraros, C.; Martin-Castillo, B.; Joven, J.; Menendez, J.A. Metformin against TGF $\beta$-induced epithelial-to-mesenchymal transition (EMT): From cancer stem cells to aging-associated fibrosis. Cell Cycle 2010, 9, 4461-4468.

94. Miyazono, K. Transforming growth factor- $\beta$ signaling in epithelial-mesenchymal transition and progression of cancer. Proc. Jpn. Acad. Ser. B 2009, 85, 314-323.

95. Wang, Q.; Tabatabaei, S.; Planz, B.; Lin, C.W.; Sluss, P.M. Identification of an activin-follistatin growth modulatory system in the human prostate: Secretion and biological activity in primary cultures of prostatic epithelial cells. J. Urol. 1999, 161, 1378-1384.

96. Lippitz, B.E. Cytokine patterns in patients with cancer: A systematic review. Lancet Oncol. 2013, 14, e218-e228.

97. Guo, Y.; Kyprianou, N. Overexpression of transforming growth factor (TGF) $\beta 1$ type II receptor restores TGF- $\beta 1$ sensitivity and signaling in human prostate cancer cells. Cell Growth Differ. 1998, 9, 185-193.

98. Krstic, J.; Santibanez, J.F. Transforming growth factor- $\beta$ and matrix metalloproteinases: Functional interactions in tumor stroma-infiltrating myeloid cells. Sci. World J. 2014, Article ID 521754.

99. Barbara, N.P.; Wrana, J.L.; Letarte, M. Endoglin is an accessory protein that interacts with the signaling receptor complex of multiple members of the transforming growth factor- $\beta$ superfamily. J. Biol. Chem. 1999, 274, 584-594.

100. Breen, M.J.; Moran, D.M.; Liu, W.; Huang, X.; Vary, C.P.H.; Bergan, R.C. Endoglin-mediated suppression of prostate cancer invasion is regulated by activin and bone morphogenetic protein type II receptors. PLOS ONE 2013, 8, e72407.

101. Hanahan, D.; Weinberg, R.A. The hallmarks of cancer. Cell 2000, 100, 57-70.

102. Ottley, E.; Gold, E. Insensitivity to the growth inhibitory effects of activin A: An acquired capability in prostate cancer progression. Cytokine Growth Factor Rev. 2012, 23, 119-125.

103. Huber, S.; Stahl, F.R.; Schrader, J.; Luth, S.; Presser, K.; Carambia, A.; Flavell, R.A.; Werner, S.; Blessing, M.; Herkel, J.; et al. Activin A promotes the TGF- $\beta$-induced conversion of CD4+CD25cells into Foxp3+ induced regulatory T cells. J. Immunol. 2009, 182, 4633-4640.

104. Chang, K.-P.; Kao, H.-K.; Liang, Y.; Cheng, M.-H.; Chang, Y.-L.; Liu, S.-C.; Lin, Y.-C.; Ko, T.-Y.; Lee, Y.-S.; Tsai, C.-L.; et al. Overexpression of activin A in oral squamous cell carcinoma: Association with poor prognosis and tumor progression. Ann. Surg. Oncol. 2010, 17, 1945-1956.

105. Fu, S.; Zhang, N.; Yopp, A.C.; Chen, D.; Mao, M.; Chen, D.; Zhang, H.; Ding, Y.; Bromberg, J.S. TGF- $\beta$ induces Foxp3 + T-regulatory cells from CD4 + CD25-Precursors. Am. J. Transpl. 2004, 4, 1614-1627.

106. Ogawa, K.; Funaba, M. Activin in humoral immune responses. Vitam Horm. 2011, 85, 235-253.

107. Yamashita, N.; Nakajima, T.; Takahashi, H.; Kaneoka, H.; Mizushima, Y.; Sakane, T. Effects of activin A on IgE synthesis and cytokine production by human peripheral mononuclear cells. Clin. Exp. Immunol. 2006, 94, 214-219.

108. Zipori, D.; Barda-Saad, M. Role of activin A in negative regulation of normal and tumor B lymphocytes. J. Leukoc. Biol. 2001, 69, 867-873.

109. Ogawa, K.; Funaba, M.; Tsujimoto, M. A dual role of activin A in regulating immunoglobulin production of B cells. J. Leukoc. Biol. 2008, 83, 1451-1458. 
110. Steller, M.D.; Shaw, T.J.; Vanderhyden, B.C.; Ethier, J.-F. Inhibin resistance is associated with aggressive tumorigenicity of ovarian cancer cells. Mol. Cancer Res. 2005, 3, 50-61.

111. Lebman, D.A.; Edmiston, J.S. The role of TGF- $\beta$ in growth, differentiation, and maturation of B lymphocytes. Microbes Infect. 1999, 1297-1304.

112. Caver, T.E.; O’Sullivan, F.X.; Gold, L.I.; Gresham, H.D. Intracellular demonstration of active TGF $\beta 1$ in B cells and plasma cells of autoimmune mice: IgG-bound TGF $\beta 1$ suppresses neutrophil function and host defense against Staphylococcus aureus infection. J. Clin. Invest. 1996, 98, 2496-2506.

113. Funaba, M.; Ikeda, T.; Ogawa, K.; Murakami, M.; Abe, M. Role of activin A in murine mast cells: Modulation of cell growth, differentiation, and migration. J. Leukoc. Biol. 2003, 73, 793-801.

114. Robson, N.C.; Wei, H.; McAlpine, T.; Kirkpatrick, N.; Cebon, J.; Maraskovsky, E. Activin A attenuates several human natural killer cell functions. Blood 2009, 113, 3218-3225.

115. Seeger, P.; Bosisio, D.; Parolini, S.; Badolato, R.; Gismondi, A.; Santoni, A.; Sozzani, S. Activin A as a mediator of NK-dendritic cell functional interactions. J. Immunol. 2014, 192, 1241-1248.

116. Mu, Y.; Sundar, R.; Thakur, N.; Ekman, M.; Gudey, S.K.; Yakymovych, M.; Hermansson, A.; Dimitriou, H.; Bengoechea-Alonso, M.T.; Ericsson, J.; et al. TRAF6 ubiquitinates TGF $\beta$ type I receptor to promote its cleavage and nuclear translocation in cancer. Nat. Comms. 2011, 2, 330.

117. Sierra-Filardi, E.; Puig-Kröger, A.; Blanco, F.J.; Nieto, C.; Bragado, R.; Palomero, M.I.; Bernabéu, C.; Vega, M.A.; Corbí, A.L. Activin A skews macrophage polarization by promoting a proinflammatory phenotype and inhibiting the acquisition of anti-inflammatory macrophage markers. Blood 2011, 117, 5092-5101.

118. Hao, N.-B.; Lü, M.-H.; Fan, Y.-H.; Cao, Y.-L.; Zhang, Z.-R.; Yang, S.-M. Macrophages in tumor microenvironments and the progression of tumors. Clin. Dev. Immunol. 2012, 2012, 1-11.

119. Condeelis, J.; Pollard, J.W. Macrophages: Obligate partners for tumor cell migration, invasion, and metastasis. Cell 2006, 124, 263-266.

120. Cozzolino, F.; Torica, M.; Lucibello, M.; Morbidelli, L.; Ziche, M.; Platt, J.; Fabiani, S.; Brett, J.; Stern, D. Interferon- $\alpha$ and interleukin 2 synergistically enhance basic fibroblast growth factor synthesis and induce release, promoting endothelial cell growth. J. Clin. Invest. 1993, 91, 2504-2512.

121. Barron, D.A.; Rowley, D.R. The reactive stroma microenvironment and prostate cancer progression. Endocr. Relat. Cancer 2012, 19, R187-R204.

122. Abe, M.; Shintani, Y.; Eto, Y.; Harada, K.; Fujinaka, Y.; Kosaka, M.; Matsumoto, T. Interleukin-1 $\beta$ enhances and interferon- $\gamma$ suppresses activin A actions by reciprocally regulating activin $\mathrm{A}$ and follistatin secretion from bone marrow stromal fibroblasts. Clin. Exp. Immunol. 2001, 126, 64-68.

123. Cho, S.H.; Yao, Z.; Wang, S.-W.; Alban, R.F.; Barbers, R.G.; French, S.W.; Oh, C.K. Regulation of activin A expression in mast cells and asthma: Its effect on the proliferation of human airway smooth muscle cells. J. Immunol. 2003, 170, 4045-4052.

124. Karagiannidis, C.; Hense, G.; Martin, C.; Epstein, M.; Rückert, B.; Mantel, P.-Y.; Menz, G.; Uhlig, S.; Blaser, K.; Schmidt-Weber, C.B. Activin A is an acute allergen-responsive cytokine and provides a link to TGF- $\beta$-mediated airway remodeling in asthma. J. Allergy Clin. Immunol. 2006, 117, 111-118.

125. Massagué, J. TGF $\beta$ signalling in context. Nat. Rev. Mol. Cell Biol. 2012, 13, 616-630.

126. Kalluri, R.; Zeisberg, M. Fibroblasts in cancer. Nat Rev Cancer 2006, 6, 392-401. 
127. Sobral, L.M.; Bufalino, A.; Lopes, M.A.; Graner, E.; Salo, T.; Coletta, R.D. Myofibroblasts in the stroma of oral cancer promote tumorigenesis via secretion of activin A. Oral Oncol. 2011, 47, $840-846$.

128. Bhowmick, N.A.; Chytil, A.; Plieth, D.; Gorska, A.E.; Dumont, N.; Shappell, S.; Washington, M.K.; Neilson, E.G.; Moses, H.L. TGF- $\beta$ signaling in fibroblasts modulates the oncogenic potential of adjacent epithelia. Science 2004, 303, 848-851.

129. Cheng, N.; Bhowmick, N.A.; Chytil, A.; Gorksa, A.E.; Brown, K.A.; Muraoka, R.; Arteaga, C.L.; Neilson, E.G.; Hayward, S.W.; Moses, H.L. Loss of TGF- $\beta$ type II receptor in fibroblasts promotes mammary carcinoma growth and invasion through upregulation of TGF- $\alpha-$, MSP- and HGF-mediated signaling networks. Oncogene 2005, 24, 5053-5068.

130. McPherson, S.J.; Mellor, S.L.; Wang, H.; Evans, L.W.; Groome, N.P.; Risbridger, G.P. Expression of activin A and follistatin core proteins by human prostate tumor cell lines. Endocrinology 1999, 140, 5303-5309.

131. Lin, S.; Ying, S.Y. Differentially expressed genes in activin-induced apoptotic LNCaP cells. Biochem. Biophys. Res. Commun. 1999, 257, 187-192.

132. Feinberg, M.W.; Jain, M.K.; Werner, F.; Sibinga, N.E.S.; Wiesel, P.; Wang, H.; Topper, J.N.; Perrella, M.A.; Lee, M.E. Transforming growth factor- $\beta 1$ inhibits cytokine-mediated induction of human metalloelastase in macrophages. J. Biol. Chem. 2000, 275, 25766-25773.

133. Loomans, H.A.; Le Bras, G.F.; Zijlstra, A.; Andl, C.D. Vanderbilt University Medical Center, Nashville, TN, USA, Unpublished data, 2014.

134. Tuxhorn, J.A.; McAlhany, S.J.; Yang, F.; Dang, T.D.; Rowley, D.R. Inhibition of transforming growth factor- $\beta$ decreases angiogenesis in a human prostate cancer-reactive stroma xenograft model. Cancer Res. 2002, 62, 6021-6025.

135. Joyce, J.A.; Pollard, J.W. Microenvironmental regulation of metastasis. Nat. Rev. Cancer 2009, 9 , 239-252.

136. Zhou, B.; Chen, W.-L.; Wang, Y.-Y.; Lin, Z.-Y.; Zhang, D.-M.; Fan, S.; Li, J.-S. A role for cancer-associated fibroblasts in inducing the epithelial-to-mesenchymal transition in human tongue squamous cell carcinoma. J. Oral Pathol. Med. 2014, 43, 585-592.

137. Kellermann, M.G.; Sobral, L.M.; da Silva, S.D.; Zecchin, K.G.; Graner, E.; Lopes, M.A.; Nishimoto, I.; Kowalski, L.P.; Coletta, R.D. Myofibroblasts in the stroma of oral squamous cell carcinoma are associated with poor prognosis. Histopathology 2007, 51, 849-853.

138. Räsänen, K.; Vaheri, A. Activation of fibroblasts in cancer stroma. Exp. Cell Res. 2010, 316, 2713-2722.

139. Kaneda, H.; Arao, T.; Matsumoto, K.; de Velasco, M.A.; Tamura, D.; Aomatsu, K.; Kudo, K.; Sakai, K.; Nagai, T.; Fujita, Y.; et al. Activin A inhibits vascular endothelial cell growth and suppresses tumour angiogenesis in gastric cancer. Br. J. Cancer 2011, 105, 1210-1217.

140. McCarthy, S.A.; Bicknell, R. Inhibition of vascular endothelial cell growth by activin-A. J. Biol. Chem. 1993, 268, 23066-23071.

141. Breit, S.; Ashman, K.; Wilting, J.; Rossler, J.; Hatzi, E.; Fotsis, T.; Schweigerer, L. Oncogene in human neuroblastoma cells: Down-regulation of an angiogenesis inhibitor identified as Activin A. Cancer Res. 2000, 60, 4595-4601. 
142. Krneta, J.; Kroll, J.; Aleves, F.; Prahst, C.; Sananbenesi, F.; Dullin, C.; Kimmina, S.; Phillips, D.J.; Augustin, H.G. Dissociation of angiogenesis and tumorigenesis in follistatin- and activin-expressing tumors. Cancer Res. 2006, 66, 5686-5695.

143. Panopoulou, E.; Murphy, C.; Rasmussen, H.; Bagli, E.; Rofstad, E.K.; Fotsis, T. Activin A suppresses neuroblastoma xenograft tumor growth via antimitotic and antiangiogenic mechanisms. Cancer Res. 2005, 65, 1877-1886.

144. Nold-Petry, C.A.; Rudloff, I.; Baumer, Y.; Ruvo, M.; Marasco, D.; Botti, P.; Farkas, L.; Cho, S.X.; Zepp, J.A.; Azam, T.; et al. IL-32 promotes angiogenesis. J. Immunol. 2014, 192, 589-602.

145. Petersen, M.; Pardali, E.; van der Horst, G.; Cheung, H.; van den Hoogen, C.; van der Pluijm, G.; ten Dijke, P. Smad2 and Smad3 have opposing roles in breast cancer bone metastasis by differentially affecting tumor angiogenesis. Oncogene 2009, 29, 1351-1361.

146. Nakagawa, T.; Li, J.H.; Garcia, G.; Mu, W.; Piek, E.; Bottinger, E.P.; Chen, Y.; Zhu, H.J.; Kang, D.-H.; Schreiner, G.F.; et al. TGF- $\beta$ induces proangiogenic and antiangiogenic factors via parallel but distinct Smad pathways. Kidney Int. 2004, 66, 605-613.

147. Guillot, N.; Kollins, D.; Badimon, J.J.; Schlondorff, D.; Hutter, R. Accelerated reendothelialization, increased neovascularization and erythrocyte extravasation after arterial injury in $\mathrm{BAMBI}^{-/}$mice. PLOS ONE 2013, 8, e58550.

148. De Bock, K.; Georgiadou, M.; Carmeliet, P. Role of endothelial cell metabolism in vessel sprouting. Cell Metab. 2013, 18, 634-647.

149. Goumans, M.-J.; Valdimarsdottir, G.; Itoh, S.; Rosendahl, A.; Sideras, P.; ten Dijke, P. Balancing the activation state of the endothelium via two distinct TGF- $\beta$ type I receptors. EMBOJ. 2002, 21 , 1743-1753.

150. Park, S.; DiMaio, T.A.; Liu, W.; Wang, S.; Sorenson, C.M.; Sheibani, N. Endoglin regulates the activation and quiescence of endothelium by participating in canonical and non-canonical TGF- $\beta$ signaling pathways. J. Cell Sci. 2013, 126, 1392-1405.

151. Bao, Y.L.; Tsuchida, K.; Liu, B.; Kurisaki, A.; Matsuzaki, T.; Sugino, H. Synergistic activity of activin $\mathrm{A}$ and basic fibroblast growth factor on tyrosine hydroxylase expression through Smad3 and ERK1/ERK2 MAPK signaling pathways. J. Endocrinol. 2005, 184, 493-504.

(C) 2014 by the authors; licensee MDPI, Basel, Switzerland. This article is an open access article distributed under the terms and conditions of the Creative Commons Attribution license (http://creativecommons.org/licenses/by/4.0/). 